\section{DENDRITIC CELLS}

\section{IRF2 directs cell distinction}

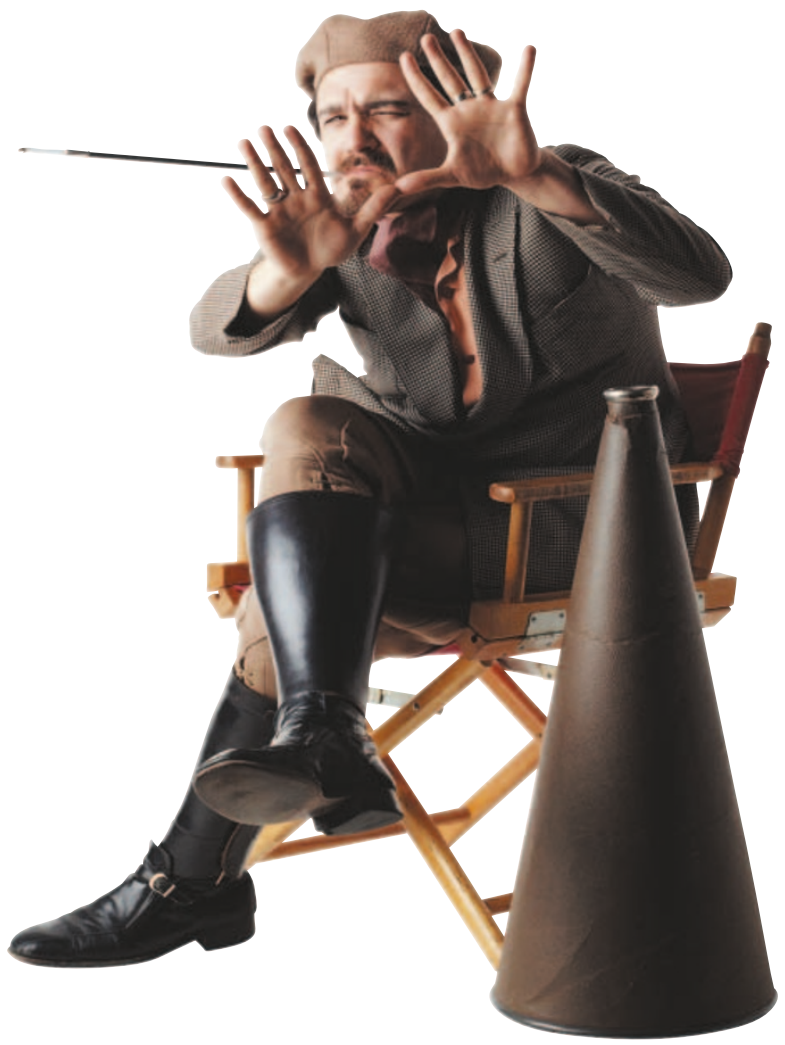

Despite the identification of distinct subsets of dendritic cells (DCs), as defined by their expression of a combination of cell-surface markers such as $\mathrm{CD} 11 \mathrm{~b}, \mathrm{CD} 11 \mathrm{c}, \mathrm{CD} 8 \alpha$ and $\mathrm{CD} 4$, little is known about the molecular mechanisms that differentially regulate their development. Now, Shinsuke Taki's group has shown that the transcription factor interferon regulatory factor 2 (IRF2) is crucial for the development of splenic and epidermal $\mathrm{CD} 4^{+}$DCs. This study is consistent with a previous report from Tadatsugu Taniguchi's laboratory showing that IRF2 is required for the development of CD8 $\alpha^{-} \mathrm{CD} 11 \mathrm{~b}^{+} \mathrm{CD} 11 \mathrm{c}^{+}$DCs.

Analysis of DC subsets in Irf2deficient mice showed a marked decrease in the number of $\mathrm{CD} 4^{+}$ CD $11 b^{+}$DCs in the spleen, as compared with wild-type animals. By contrast, other DC subsets were present at normal frequencies or, in the case of $\mathrm{CD} 8 \alpha^{+} \mathrm{CD} 11 \mathrm{~b}^{-} \mathrm{DCs}$, at slightly increased numbers. Further examination showed that in the epidermis of the Irf2-deficient mice, the subset of

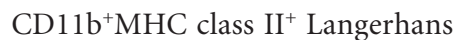
cells (LCs) expressing cytoplasmic CD4 was severely depleted.
By generating reciprocal bonemarrow (BM) chimaeras, it was shown that the reduction in splenic $\mathrm{CD} 4{ }^{+} \mathrm{CD} 11 \mathrm{~b}^{+} \mathrm{DC}$ numbers was a result of Irf2 deficiency in BMderived progenitor cells. This cellautonomous role for Irf2 was also observed in BMDCs: fewer CD11 $\mathrm{b}^{+}$ $\mathrm{CD} 11 \mathrm{c}^{+} \mathrm{DCs}$ were generated after in vitro culture of Irf2-deficient BM cells than wild-type BM cells. In addition, BMDCs from Irf2-deficient mice were less mature and did not fully upregulate the expression of CD40 or CD86 after stimulation with lipopolysaccharide (LPS) or unmethylated CpG DNA, indicating a role for Irf2 in the maturation of DCs, at least in vitro. However, the requirement for Irf2 in BMDC maturation is not absolute, as the levels of cytokines produced by LPSand CpG-stimulated Irf2-deficient BMDCs were indistinguishable from those produced by similarly treated wild-type BMDCs.

Irf2 has previously been shown to attenuate signals induced by interferon- $\alpha$ (IFN- $\alpha)$ and IFN- $\beta$. The numbers of splenic $\mathrm{CD} 4^{+} \mathrm{CD} 11 \mathrm{~b}^{+}$ DCs and epidermal LCs expressing

\title{
REGULATORY T CELLS
}

\section{Reduction in regulation}

Selective depletion of the $\mathrm{CD} 4^{+} \mathrm{CD} 25^{+}$ regulatory $\mathrm{T}\left(\mathrm{T}_{\mathrm{Reg}}\right)$-cell subset in mice induces the spontaneous onset of autoimmune diseases. However, although human $\mathrm{CD} 4{ }^{+} \mathrm{CD} 25^{\mathrm{hi}} \mathrm{T}$ cells can elicit suppressive functions in vitro, there was little evidence of a role for these cells in vivo, until a study by Viglietta et al. showed that $\mathrm{CD} 4^{+} \mathrm{CD} 25^{\text {hi }}$ T cells in patients with multiple sclerosis (MS) have defective regulatory function. It is easier to activate autoreactive $T$ cells isolated from patients with autoimmune diseases than those from healthy controls. So, the authors set out to compare $\mathrm{CD} 4^{+} \mathrm{CD} 25^{\text {hi }} \mathrm{T}_{\mathrm{Reg}}$ cells isolated from untreated patients with relapsing/remitting MS and healthy control individuals. Initial analyses indicated no difference between the two groups in the level of expression of CD25, or in the frequency of $\mathrm{CD} 4{ }^{+} \mathrm{CD} 25^{+}$or $\mathrm{CD} 4^{+} \mathrm{CD} 25^{\text {hi }} \mathrm{T}$ cells in the blood. By contrast, when compared with $\mathrm{CD} 4^{+} \mathrm{CD} 25^{\mathrm{hi}} \mathrm{T}_{\mathrm{Reg}}$ cells purified from healthy controls, $\mathrm{CD} 4^{+} \mathrm{CD} 25^{\text {hi }}$ $\mathrm{T}_{\mathrm{Reg}}$ cells isolated from MS patients were markedly impaired in their ability to suppress $\mathrm{CD}^{+}{ }^{+} \mathrm{CD} 25^{-} \mathrm{T}$-cell proliferation and interferon- $\gamma$ production induced by platebound CD3-specific antibody. This lack of suppression resulted from a loss of regulatory function by the $\mathrm{CD} 4^{+} \mathrm{CD} 25^{\text {hi }} \mathrm{T}$ cells and not a defect in the $\mathrm{CD} 4^{+} \mathrm{CD} 25^{-} \mathrm{T}$ cells, as $\mathrm{CD} 4{ }^{+} \mathrm{CD} 25^{\text {hi }} \mathrm{T}_{\text {Reg }}$ cells from healthy individuals were able to suppress autologous $\mathrm{CD} 4{ }^{+} \mathrm{CD} 25^{-} \mathrm{T}$ cells and those derived from MS patients equally. In reciprocal studies, the $\mathrm{CD} 4^{+} \mathrm{CD} 25^{\text {hi }} \mathrm{T}_{\text {Reg }}$ cells from MS patients could not suppress proliferation of $\mathrm{CD} 4^{+} \mathrm{CD} 25^{-}$ $T$ cells from either healthy individuals or MS patients.

The $\mathrm{CD} 4^{+} \mathrm{CD} 25^{\mathrm{hi}} \mathrm{T}_{\mathrm{Reg}}$-cell population in MS patients was shown not to be diluted by recently activated cells involved in the ongoing MS-associated immune response in three ways. First, $\mathrm{CD} 4{ }^{+} \mathrm{CD} 25^{\text {hi }} \mathrm{T}$ cells in both
MS patients and healthy individuals were anergic; second, the $\mathrm{CD} 4{ }^{+} \mathrm{CD} 25^{\mathrm{hi}} \mathrm{CD} 62 \mathrm{~L}^{+}$ cells, which contain no potentially activated CD62 $\mathrm{L}^{-} \mathrm{T}$ cells, from MS patients were unable to inhibit $\mathrm{CD} 4^{+} \mathrm{CD} 25^{-} \mathrm{T}$-cell proliferation; and third, $\mathrm{CD} 4^{+} \mathrm{CD} 25^{\text {hi }} \mathrm{T}$ cells isolated from a healthy individual before and after vaccination against influenza virus to induce an ongoing immune response were equally capable of suppressing $\mathrm{CD}^{+} \mathrm{CD} 25^{-} \mathrm{T}$-cell proliferation.

These data provide the first evidence that a defect in $\mathrm{CD} 4{ }^{+} \mathrm{CD} 25^{\text {hi }} \mathrm{T}_{\mathrm{Reg}}$-cell function can be linked to an autoimmune disease in humans. Further work is needed to determine whether such dysregulation can be viewed as a risk factor for autoimmunity. However, the authors' initial studies showing that $\mathrm{CD} 4{ }^{+} \mathrm{CD} 25^{\text {hi }} \mathrm{T}$ cells from patients with thyroiditis and psoriasis have reduced regulatory function indicate that this hypothesis might hold up.

Karen Honey

(2) References and links

ORIGINAL RESEARCH PAPER Viglietta, V. et al. Loss of functional suppression by $\mathrm{CD} 4^{+} \mathrm{CD} 25^{+}$regulatory $T$ cells in patients with multiple sclerosis. J. Exp. Med. 199, 971-979 (2004) 